\title{
Aquinas and Solovyov: Unified Christian ontological-epistemology in critique of epistemic reductivism
}

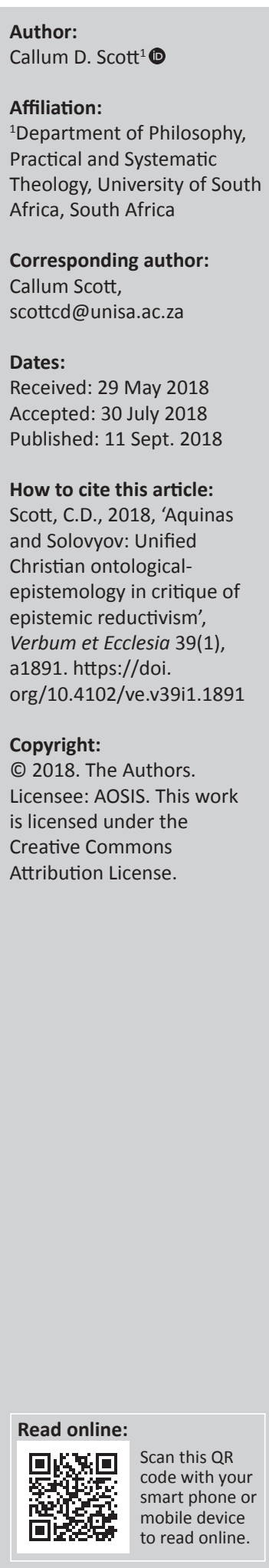

Modern positivism reduced 'being to knowing', considering being as cognitively inaccessible and its study as meaningless. In recent 'scientistic' scholarship, these presuppositions have found new life. However, Christian ontologically founded epistemology is concerned by this dismissal of being. In search of an ecumenical response, this work attempts a multi-patrimonial Christian, philosophical counterargument to reductive anti-metaphysical epistemology. A comparative analysis between the ontological epistemologies of Saint Thomas Aquinas (as representative of the Mediaeval Occidental Christian tradition) and Vladimir Solovyov (a modern, eastern Christian philosopher-theologian) is made. In this contrast, it is argued that a harmonic Christian philosophical voice is evident. In both Western and Eastern approaches, the causal complexity of being - by the fact that being is - implores the philosopher for a unified account, in contradiction to anti-metaphysical reductivism in any of its forms.

Intradisciplinary and/or interdisciplinary implications: Bringing the Christian metaphysics and epistemology of Aquinas and Solovyov into conversation, which the author has not seen done in other literature, this work brings together Epistemology and Metaphysics, leading to a unified practical application in the critique of issue within contemporary Philosophy of Science, scientism.

\section{Introduction}

The contemporary person - whether of faith, science or both - is located within the context of a much-debated academic dialectic. For example, a scholar like Richard Dawkins supposes that science is the only reasonable epistemological method ([2006] 2009). Oftentimes scientists of faith have argued for a more integrated perspective thereupon when compared to their fundamentalist kin (Numbers [1992] 2006; Peacocke 2001; Polkinghorne 2000). Perhaps unknowingly, the person of faith and the scientist find their being within a non-integrated, contended milieu.

The aim of this research is to address this existential problematic. This will be achieved by presenting an ecumenical Christian philosophical response to one of the underlying factors of the tension, namely, a reductivist epistemology that oftentimes denigrates metaphysics.

A nuanced paradigm is proposed, following a historical reconstructivist, comparative methodology. Two Christian scholars, representative of the philosophical traditions of Western and Eastern Christianity - namely Saint Thomas Aquinas and Vladimir Solovyov, respectively will be compared, with congruent themes relevant to this study identified. An extrapolation to the problematic of epistemic reductivism's historical development and its continuing legacy in positivistically inspired approaches to knowledge is finally undertaken.

\section{Modernity's legacy to metaphysics and epistemology}

The historical classification of world history into pre-modern, modern and other clearly defined periods carries a Eurocentric bias. In this research, indulgence is begged for the employment of the term 'Modernity', however, as much of what will be argued for centres on alternatives to the modern western paradigm. Although 'Modernity' is contentious, in broad terms it refers to a historical period originating in the 16th century, bound up with the cultural and intellectual movement of the Renaissance (Parker 2007:1). Steadily born out of the Renaissance were both the humanist ideology (which directed to the autonomy of the individual) and the Scientific Revolution (Boas 1962; Delanty 2013; Parker 2007:1). 
Within Modernity, the 'Enlightenment' forms a sub-period, dating from the latter 17th century, characterised by appropriately modern worldviews (Davies 2016). This moment witnessed the emergence of the modern 'thinking subject', reliant upon reasoning and measuring abilities. Indeed, the self-directedness of the modern man was spurred on by the Renaissance's scientific discoveries by the likes of Nicolas Copernicus (1473-1543) and Galileo Galilei (1564-1642). ${ }^{1}$ By science, the Modern man began to free himself from his 'inability to make use of... [his] own understanding without direction from another' (Kant [1784] 1996:17). ${ }^{2}$ Coupled with the Scientific Revolution, Immanuel Kant argued for a cognitional 'Copernican Revolution' ([1787] 2010:13-14). He proposed that the 'Enlightenment person' was to be liberated from 'minority' through subjectivity; even objects were deemed as created by the subject's intuition ([1784] 1996:17; [1787] 2010:9, 13). ${ }^{3}$

The Kantian analysis is a poignant indication of the modern condition and the problematic situation of metaphysics: in the age of scientific empiricism, and not knowable a posteriori, metaphysics is a discipline - not expelled, but - relocated to epistemological suspicion (MacDonald 2009:xiii). Considered more charitably, though, Modernity is marked by the desire for better understanding of phenomena through the division of knowledge into its constituent parts (Newell 2009:179). Indeed, it gave priority to the rational and the sensorily perceivable, in the epistemic movements of rationalism, empiricism, positivism and scientism (Ayer [1936] 1990:16; Carnap 1961; Descartes [1637] 2007; Locke [1689] 2004). It may be interpreted, though, that in the marginalisation of being for the sake of reductive verification, the consequence of Modernity was the rejection of metaphysics (Ayer [1936] 1990:14; Ladyman et al. 2007).

In the 16th century, Francis Bacon argued that universal entities are apparent within perceivable, physical phenomena, verifiable by empirical means (Bacon 1854:348; Voegelin 1948:2). Isaac Newton (1729:393) put a similar stance forward. The empirical focus on the verifiable evolved into antimetaphysicalism, through the influence of David Hume in the following century ([1748] 2008). Hume, in turn, influenced Auguste Comte's empirical attempt to explain physical entities without metaphysics (Comte [1864] 1896b:302; Crotty 1998:22; Pickering 2006:312; Scott 2016). ${ }^{4}$

Comte discerned that a universal, fundamental law is present throughout all human knowledge ([1864] 1896b:302-303).

1.'Man' is used not without an awareness of gender inclusive language, but to recognise the dominance of patriarchy in this period of European history.

2.'Have courage to make use of your own understanding! is thus the motto of enlightenment' (Kant [1784] 1996:17).

3.It has hitherto been assumed that our cognition must conform to the objects; but all attempts to ascertain anything about these objects a priori... have been rendered abortive by this assumption. Let us then make the experiment whether we may not be more successful in metaphysics, if we assume that the objects must conform to our cognition' (Kant [1787] 2010:13).

4.'The Positive Philosophy is distinguished... by nothing so much as its rejection of all inquiry into causes... [thus]... observed facts are the only basis of sound speculation... no proposition that is not finally reducible to the enunciation of a fact... can offe any real and intelligible meaning...' (Comte [1864] 1896b:302-303).
This law is the process of epistemic development through theological, metaphysical and - the pinnacle - positive scientific knowledge founded upon empirical observation ([1864] 1896b:302-303). ${ }^{5}$ Through observation and reason which are thought to be at the foundation of all perceived phenomena - the singular task of positive science arises: the making of natural, universal laws apparent ([1864] 1896a:14). Metaphysical and theological problems - such as causality, teleology, etc. - are, therefore, anathema to the immediacy of positivist empiricism ([1864] 1896a:2). Positive science holds three characteristics: the belief that structures of phenomena can be made apparent only through the scientific method; based upon subjective observation and reason, knowledge can never be absolute; and the rejection of non-empirical metaphysics (Zenkovsky 1953:707-708). ${ }^{6}$ Positivism, nevertheless, presupposed that being can be accounted for through reductivist, sensorily based knowing and that any content not reducible as such was dismissible, thus committing the epistemic fallacy (Bhaskar [1978] 2008:16, 1998:27-28).

Identifying with the positivist tradition, some contemporary scientists classify their research as 'scientistic', as they deem natural science and its associated empirical methods as the singular route to knowledge (Carnap 1961:254; Comte [1864] 1896b:302-303; Pigliucci 2015:569; Scott 2016). Although the embracement of scientism has been associated with writers of popular scientific works, support for positivist and materialist metaphysics has been given by philosophers, too (Dawkins 2003; Harris 2006; Hawking 2001; Hawking \& Mlodinow 2010; Mi \& Chen 2007; Rouse 2002). ${ }^{7}$ Entailed is the hypothesis that natural science has pre-eminence over knowledge systems (Ladyman et al. 2007:39). These foundational ideas tie closely with empirical science's preeminence because of its explanatory adequacy, for example (Carnap 1961:254). However, a number of philosophical works have been critical of this reductivism (Dupré 1988; Gleiser 2014; Haack 2003; Maffie 1995; Olafson 2001; Sorrell 1991; Stenmark 2001; Williams \& Robinson 2015). Indeed, requiring that entities be measurable by the empirical scientific method - if it is by virtue of this method that all valid knowledge arises - the metaphysical assumption of physicalism is presupposed. Consequently, for non-empirical discipline, scientism's verdict is clear: The immeasurability of the unknowable, or not yet known, disqualifies such pursuit from 'science' (Scott 2016).

5.For example, in the theological state, the mind actively seeks out divine action in causality so preventing the consideration of the scientific/positive system, wherein both empiricism and reason are the fundamental tenets guiding the acquisition of knowledge (Comte [1864] 1896b:2). In fact, that true knowledge must be founded in observation forms an irrefutable tenet of positivist thought ([1864] 1896b:2).

6.The fact that positivism includes the embracement of materialist metaphysics is not significant for positivists (Zenkovsky 1953:708). Comte, in fact, acknowledged the theory-laden nature of observation to be the product of the thinking subject alone (Comte [1864] 1896a:4; Solovyov 1996:154). If theory - which is the product of the subject - precedes observation, a caution is present from the foundations of positivist thought: observation does not "give' objectively perceived phenomena to
the observer.

7.James Ladyman et al. embrace scientism absolutely, reducing metaphysics to the empirically verifiable (2007:61-62). In explaining what they would find to be an empirically verifiable (2007:61-62). In explaining what they would find to be an
acceptable 'scientistic metaphysics', only a metaphysics that natural scientists could accept as legitimate is tolerable $(2007: 1,65)$. 
Despite the modern denial of metaphysics or of the difficulty of the thinking subject reaching to the metaphysical reality, being remains, but without an account, for empirical science alone cannot provide a priori knowledge of causality (Ayer [1936] 1990:14; Lonergan [1957] 1970:653). According to Bernard Lonergan - contrary to Kant and later metaphysically reductive Moderns - being's intelligibility is founded in the subject's rationalisation of the contingence of being, hence alluding to the accessibility of the metaphysical ([1957] 1970:638-639, 656-657).

In the 20th century, Martin Heidegger was among the philosophers principally associated with both metaphysics and the problem of being. Infamously, Heidegger argued for the abandonment of metaphysics (Heidegger 2000:39; 2005:257; White 2009:21). His research directed him to argue that the focus of this philosophical sub-discipline was not particular being - as in a thing's existence - but the more general concept of 'Being', which is not detectable in particularities (2000:4,36). Thus, metaphysics abstracts from instances of being to the 'Being of being', the cause of being (Heidegger 2000:20, 34; Stone 2006:225). However, argues Heidegger, Being is not knowable from instances of being, for the subjective knower is constrained as being in Being (2000:1-2, 36, 38). To the subject, Being thus remains hidden, even unknowable (2000:39). If this is correct, then it follows that questions of causality - metaphysical questions - should be abandoned and metaphysics as an enterprise, overcome (2000:39).

The Heideggerian abandonment of metaphysics should be interpreted differently, however. His is not a rejection of Being, but a reframing of the way in which Being is considered: to a non-consideration. Heidegger does not deny Being, but attempts to redeem it from reduction to 'an effervescent vapour' (2000:53). His appeal to the philosopher is to leave beings to be (2005:250). To leave beings to be, to leave Being to be, necessitates overcoming metaphysics. Yet, virtually acknowledging the point upon which he would be critiqued, Heidegger notes, '[o]ur thinking... remains on the path of metaphysics' (2005:257). In attempting to 'overcome' metaphysics, Heidegger continues to do metaphysics by taking a reflective stance on how metaphysics should not be done (Desmond 2005:231).

The Heideggerian metaphysical overcoming is at the core of Jean-Luc Marion's theology that 'being' should be severed from 'God' (Heidegger 1978:436; Marion 1991:16). As with Heidegger's silence on the content of Being, Marion proposes that the utilisation of any term - for example 'Being' employs human understanding to grasp 'God' (Heidegger 2005:256; Marion 1991:59). What is understood is thus a constructed, limited interpretation of 'God', an idol of 'God', but not 'God' (Marion 1991:59). In Heideggerian phraseology, God should be left to be, and 'Being' - an idol of God removed from theology, for faith does not need being (1991:62-63). Ultimately, Marion posits, the theological interpretation of God as equated to primary, First Being, is not a determination of 'God', but of the theologian (1991:80). Silence, rather, is the only adequate response (1991:107).

As a contingent being, the human experience of her own limited nature would suggest that no being can cause its own being, therefore, it follows logically that being is caused and it can be inferred that being has a necessary cause (Scott 2014:234). So intimately has the bond between being and necessary cause (interpreted theologically as 'God') been argued for, that Lonergan ([1957] 1970) contended:

[I]t is one and the same thing to understand what being is and to understand what God is (p. 658).

The position assumed herein is that there is a disparity between ontological reality and epistemological explanation of being and the Being of being. Thus, although philosophical terminology will always be restricted by human categories of understanding, the ontological entity remains unscathed. Were epistemic account not sought, though, the philosophicalquestioning - dimension of the subject would be quelled by merely resting in silence - in itself a metaphysical perspective.

Placing being aside is a problematic metaphysical position for the Judaeo-Christian intellectual tradition, too, as Sacred Scripture reveals. Saint Paul, for instance, spoke of God as the Being within which all beings have their being (Ac 17:24). Moreover, the first verses of Genesis reference the necessary dependence of all things upon God for being. This fundamental dogma - of being's contingency - was codified by the Council of Nicaea in $325 \mathrm{CE}$, and has been professed by both Eastern and western Christians ever since (Bindley [1899] 1906:14-15, 17). In light of the rejection of being, a Christian response is required (Aquinas, 2012, Summa Theologica, I, q. 45, a. 5).

Rather than offering a single-faceted retort, though, this work is inspired by the ecumenical theology developed by the Western and Eastern Churches in the past half-century. ${ }^{8}$ Employing a Thomist framework and seeking suitable philosophical representatives from the Christian West and East, the author was led to a note of Hans Urs von Balthasar (1986):

[Vladimir] Soloviev's skill in the technique of integrating all partial truths in one vision makes him perhaps second only to Thomas Aquinas as the greatest artist of order and organization in the history of thought (p. 284).

Aquinas and the Eastern Orthodox Vladimir Solovyov have been related in passing in a number of recent Englishlanguage texts (cf. Glazov 2016:7-9; Nollan 2008:5; Wozniak 2013:339-340). ${ }^{9}$ More direct juxtapositions have been

\footnotetext{
8.From the Western perspective, Pope Paul Vi declared hope that the barriers would be overcome between churches '... so that at last there may be but the one dwelling... firmly established on Christ...' (1964, Decree on Ecumenism - Unitatis Redintegratio, $\$ 14,18)$. The Ecumenical Patriarch of Constantinople, Bartholomew I, the first among equals of the Orthodox patriarchs, similarly declared:

[We seek] the rapprochement of these two most ancient Churches... unity is mandatory and must be pursued within the framework of... the Church before the Schism [of 1054 CE] (2011:187).

9.Vladimir Sergeevich Solovyov (in the Russian: 'Владимир Сергеевич Соловьев' [the surname has been transliterated variously also as Solov'ëv, Soloviev, and Solovyev])
} 
undertaken in Russian research, for example in the work of Dushin (2005). ${ }^{10}$ The Orthodox reception of Aquinas began when the Summa contra gentiles and Summa Theologica were translated into Greek by Demetrios Kydonnes - who was critical of Aquinas' rationalism - by 1354 and 1364, respectively (Yannaras 2006:3, 11). ${ }^{11}$ Later, Greek theologians like John Karyophylles (c. 1600-1693), Elias Miniates (1669-1714) and Christos Androutsos (1869-1935) employed aspects of Aquinas' works (Yannaras 2006:87, 89-90, 202-205). Unlike the Greeks, by the 19th century, the Russian patriarchate was characterised by anti-Scholastic, Slavophile theological discourse, wherein figures like Ivan Kireevsky (1806-1856) and Alexei Khomiakov (1804-1860) argued contrary to western rationalism (Plested 2012:179-181). Of importance, then, is the divergence between Solovyov and his Russian peers, Solovyov approached the Scholastic Aquinas rather charitably and had regard for his theological aesthetics (2012:182-183). An additionally striking note was Solovyov's focus upon unity; in opposition to multiple 20th-century Orthodox theologians who would engage in 'dialectical theology', oftentimes focusing on Aquinas' thought (2012:183).

The careful reading of the works of Aquinas and Solovyov will reveal analogous perspectives to the contrary of metaphysical reductivism and 'overcoming'. For although the earlier mentioned critiques of the Moderns and Heidegger and Marion serve as significant problematics to the metaphysical stances of Saint Thomas and Solovyov, in both cases, their metaphysics holds out. This may be doggedly so because Aquinas and Solovyov consider empirical science and metaphysics as epistemically synchronous (Aquinas n.d., Expositio libri Posterium Analyticorum: Commentary on the Posterior Analytics of Aristotle, Lectio 4, Caput 2; Kanne 1979:145-148; Jakim in Solovyov 1996:8; Solovyov 1996:11). Thus, the fundamental theme of this study is a determination of the extent to which Aquinas and Solovyov argue in consort against the modern fragmentation of knowledge, as particularly present in positivist reductivism. A contribution made by this research is that it seeks to juxtapose the metaphysical epistemology of Aquinas and Solovyov, proffering an exposition not yet made in English-language research.

\section{(footnote 9 continues...)}

was considered by the Jewish-born, Russian, Christian philosopher, Semën Frank as '... the greatest of Russian philosophers...' ([1950] 2001], 9), an accolade added to by Randall Poole (2010:131) and Thomas J. Gerrard (1918:1) who both commended Solovyov as Russia's foremost religious philosopher. Born on 16th commended Solovyov as Russia's foremost religious philosopher. Born on 16th anunary 1853 in Moscow, Solovyov's family was prestigiously academic: his father Serge Mikhaïlovitch Solovyov was the principal Russian historian of this time and his mother, Polyxene Vladimirovna Roman philosopher, Hryhorii Skovoroda (Gerrard 1918.51; Poole 2010:131). Solovyov's Russian contemporaries came to be divided between the more traditiona 'Slavophiles' (who sought to maintain Oriental thought and customs) and the 'Occidentalists' (deeply influenced by the positive philosophy of Auguste Comte) (Gerrard 1918:5). This discord encouraged Solovyov's own via media - his 'philosophy of unity' (vsëedinstvo) - wherein he attempted to bridge the chasm between ideologies: occidental and slav, faith and science, Church and State, and Catholicism and Orthodoxy (Gerrard 1918:5; Jakim, in Solovyov 1996:8; Poole 2010:132). Although some contention exists as to Solovyov's 'Orthodoxy' - due to his openness to the papacy - he was nevertheless an Eastern Christian by his own insistence (1948:32).

10.Due to the author's unfamiliarity with the Russian language, more in depth research into Russian philosophical-theological works on Solovyov and his comparison to Aquinas has not been possible.

11.Yannaras notes with critical tone that Aquinas' rationalism in particular took the form of transforming God into a logical, '... intellectual being... What is missing is the experiential basis of the Christian Gospel...' (2006:37).

\section{Methodology}

Some theories from philosophy's past are irrelevant to the contemporary inquiry (Gracia 1992:135). However, within philosophical discourse, certain perennial, themes remain as pertinent to the philosophy of the past as to that of the present, continuing to provoke the philosophical imagination (1992:139). An example relevant to this discussion is the fundamental metaphysical problem. ${ }^{12}$ The task of the historicist philosopher is thus 'perforce an endless enterprise', through which constructs from the past challenge and offer multifarious perspectives on contemporary themes without risking anachronicity (Gracia 1992:147; Pieper 2006:312; Raju [1962] 1992:300).

As this research discerns contemporary relevance in the historical constructs of both Saint Thomas Aquinas and Vladimir Solovyov - as will be developed - the philosophical method of historical reconstructivism is appropriate (Liat 1951:12-13). Given that our objective is not only to historically reconstruct and apply the metaphysical epistemologies of Aquinas and Solovyov but also to draw a comparison between them, a further methodological clarification is required (1951:12-13).

The method of 'comparative philosophy' is usually understood as the juxtaposing of multiple cultures' 'histories and traditions of philosophy', by recognising the value of diverse cultures' philosophical pursuits (Raju [1962] 1992:292, 297). Comparative philosophy's result is often the unearthing of cognate themes between traditions ([1962] 1992:292). Though a thematic approach could be taken, the contrasting of particular philosophers' theories from different traditions may also be done. Equating Aquinas and Solovyov falls into this latter approach, as respectively they belong to Western and Eastern Christianity.

\section{Solovyov's critique of positivism}

An Enlightenment-like appreciation of science bloomed in modern Russia (from the 1860s), and with it, the exultation of the scientific method and its results (Zenkovsky 1953:706-707). Sympathetic to Comte's theoretical constructs, some Russians embraced positive philosophy (Jakim in Solovyov 1996:349; Walicki 1979:349; Zenkovsky 1953:707). ${ }^{13}$ The Comteandynamic is displayed, for instance, in the arguments of Vladimir Viktorivich Lesevich (1837-1905), who proposed that thoughts begin in the perceptual process as knowledge is given directly from material entities (Zenkovsky 1953:708-709). Lesevich also expressed antipathy to metaphysics (Lesevich 1877:151 in Zenkovsky 1953:710). Another Russian positivist, Nicholas Yakovlevich Grot (1852-1899), argued for metaphysics' removal from scientific discourse (Grot 1904:10, 145 in Zenkovsky 1953:716). Positivism, in all likelihood, was influential in Russian society, including among its natural scientists, as its leitmotif is detectable in the political enforcement of dialectical 12.'Why does something exist rather than nothing?' (Leibniz [1714]2006).

13. However, the 'official' Soviet history of Russian positivist philosophy attempted to downplay Comte's influence (de Courten 2004:194). 
materialism following the 1917 Bolshevik Revolution (Poole 2003:132; Zenkovsky 1953:719).

It is not surprising that Solovyov was familiar with Comtean positivist thought (De Courten 2004:195).${ }^{14}$ By virtue of his epistemological union of metaphysics and empiricism, Solovyov's opposition to the positivist rejection of metaphysics is predictable $(1996: 11,34)$. Comte had argued that the two foundations of positive philosophy were rationalism and empiricism (Comte [1864] 1896a:2). It was, therefore, to these basic tenets that Solovyov directed his critique through a historical interpretation of western philosophical history that he judged as relevant to positivism.

In the Solovyovian account, rationalism emerges in perspectives such as that articulated by the 9th-century neoPlatonist John Scotus Eriugena, who contended that reason has priority (John the Scot [1976] 2011:91; Solovyov 1996:14-15). Such argumentation can lead to the falsely dichotomous construal that if the reason was foremost then other sources of knowledge were subordinate. Among these was faith, an abhorrence to reason (1996:16). In arguments as Solovyov's interpretation of Eriugena, nature - the immediately apparent became Scholastic reason's focus (1996:17). ${ }^{15}$ Not only was reason placed in a dualistic relationship with faith but also, Solovyov argues, it was cognitively severed from nature, as reason had to supplant the object with which it was concerned (1996:17). Such dualism was supremely manifest in the rise of Modernity, evidenced by René Descartes' sacrifice of all reality to reason ([1637] 2007:17). Reason's prizing absolved the verification requirement by the thinker about the thing to being: All that exists is understood as graspable and construed by reason (Solovyov 1996:18, 20).

Despite the rationalist turn away from extant entities, Solovyov indicated that a variety of rationalism emerged with materialist undertones in the anti-causalism of Baruch Spinoza (1996:21). In Spinoza's determination, the being of any entity can be construed by the understander, however, the essence of the being of the thing is both prior to, and has primacy over, the act of understanding (Ethics: Part I. Concerning God, Proposition VII). Solovyov considered Spinoza's rationalism as more satisfactory than Descartes' radical scepticism (1996:22). However, Solovyov took issue with Spinoza's rejection of the metaphysical question of causality because he assumed being, without querying its emergence (Solovyov 1996:22; Spinoza [1677] 2001).

Solovyov's historical survey makes the contention that the movement against metaphysics was strengthened through the empiricists. The essential doctrine of empiricism became

14.Solovyov devoted an entire text to this critique - The Crisis of Western Philosophy (Against the Positivists) - including a precise counter to Comte as an appendix (1996:150-168). This text is employed in this research.

15.Although Solovyov claims that the Scholastics demonstrated a 'rejection of religious dogma' in the giving of primacy to reason, this statement should not go unchallenged (1996:16). It would have been fairer for him to clarify his statement with the determiner 'some', given the significant place of religious dogma in with the determiner 'some, given the significant place of religious dogma in Scholastic works like Aquinas' Summa Theologica, and even the complimentary
and interconnected role given to reason and faith by Augustine (1887), Anselm (2000) and Aquinas (2008, Truth, Vol. I, Q. 2, A. 1) the second tenet of positivism: though the being before the thinker necessitated account, non-empirical musings were rejected in reaction to rationalism. Thomas Hobbes, for instance, regarded metaphysical terms as 'meaningless vocal sounds', adopting an extreme physicalism - a metaphysical propositionwhich holds that apart from the physical, nothing has being (Hobbes [1656] 1981:29; Solovyov 1996:29). Hobbes' empiricist contemporary, John Locke, argued that understanding sprang forth from sensory observation of the physical and mental processes as the only sources of knowledge (Locke [1689] 2004:18). Here Solovyov was critical, too, for although Locke deemed substance as possessing existence, he could not permit the thinking subject to have knowledge of the thing perceived (Solovyov 1996:30). Rather, knowledge obtained via observation is only knowledge of the sensory data about the thing held.

Implicit in empiricist epistemology, Solovyov proposes, is the problem that the knowable of extant matter is comprised of subjective representations of entities - generated through observations of things - which are assumed to exist extra to the thinking subject rather than of things themselves (1996:30). Knowledge in the empiricist's conceptualisation is herein severed from being, as no causal account of being is provided. ${ }^{16}$ This, Solovyov argues, is a consequence of the dilemma imposed upon epistemology by empiricism, that is, that if all that can be known are sensory representations, then, non-sensorily founded knowledge is fanciful (1996:33). The idealist Kant, acknowledged the influence that such Humean metaphysical scepticism had upon his own conclusion that metaphysical reality is ungraspable ([1783] 2007, [1787] 2010:211, 453). ${ }^{17}$ For rather than the thinking subject ever being able to gain access to the metaphysical Ding an sich, it was only the object - construed by the coupling of reason and sensory observation - which was classifiable by the subject's categories, properties and means (Solovyov 1996:37, 47-48). ${ }^{18}$ If no data of the 'thing-in-itself' can be known, no assertion of that thing's being can be made. For nothing about the thing is knowable apart from the subject's representations. ${ }^{19}$ In this denial of access to metaphysical reality, a physicalism arises in empiricism and idealism.

These epistemological schools at the core of positivism led to the conclusion that, '... only phenomena, not the entity in itself' can be knowable (1996:57-58, 60). However, since Comtean positivism observes the empirical, by consequence, positivism is only of importance to phenomena that can be studied empirically (1996:165). Significantly, metaphysics must be excluded from the universalisation of positivism across all knowledge ([1864] 1896b:302-303). ${ }^{20}$

16. [The fruit of rationalism and empiricism is that] external material being loses... all its independence, being recognised as only a representation' (Solovyov 1996:32).

17.'[O]ur faculty of cognition is unable to transcend the limits of... experience...' (Kant [1787] 2010:15).

18.It should not be forgotten that Kant sought to rescue objectivity and metaphysics through 'practical reason' ([1787] 2010:453).

19.Taking Kantian metaphysical scepticism's problematic to its conclusion, G.W.F. Hegel came to hold that existence is only in concepts (1900:9).

20.'[But, if the domains of positive science and metaphysics] are wholly other... to assert that positive science must replace... the... metaphysical world-view is simply meaningless' (Solovyov 1996:165). 
In this manner, Solovyov argues, the positivist application of itself as the sole method for knowledge acquisition was unsuccessful (1996:165). With origins in a misconstrual of the delineations between empirical and non-empirical science, positivism could not force all knowledge to bend to its subjectivist, empirical methodology, because not all knowledge is empirical (1996:168). Indeed, argues Solovyov, as being remains existent beyond the subject - and by extension cries out upon the subject's encounter with it for a causal explanation - it cannot be limited to subjective representation alone (1996:23, 63). In fact, in the dialogical generation of knowledge of the world, a meeting between being and the thinking subject must be presupposed (Solovyov 1996:63). Solovyov (1996):

A representation presupposes that which represents and that which is represented-a subject and an object... An object is only the representation of a subject, while a subject is only that which represents an object (p. 64).

Herein, Solovyov's intricate interplay between ontology and epistemology in the construction of knowledge is beheld, avoiding the reduction of knowledge to the subject's observational data alone (made manifest in representations). This dynamic places positivism in opposition to Solovyov's unified epistemology: the knower is not removed from the known as is in positivist representative epistemology (1996:74, 150). Solovyov was critical of this knowledge remaining behind the veil of subjective construal. ${ }^{21}$ There is more to be known than has been obtained through immediate observation, as demonstrated by empirical science's constant state of development (1996:72-73). The question of the post-Kantian, modern philosopher, however, needs to be answered: 'How do we find... that which is not representation?' (1996:72)

In Solovyov's ontological-epistemology - the core of his Modernist critique - he acknowledges that there is more that is extant than the immediately sensorily perceivable and cognitively representable (1996:74). This he considers the beginning point of transcending representations in order that the unmediated Ding an sich may be reached (1996:74). Contrary, then, to the positivist attempt at negating metaphysics, Solovyov re-centres metaphysics, and ascribes to it the task of becoming the means to the knowledge behind empirically founded representations. ${ }^{22} \mathrm{He}$ posits that metaphysical knowledge of the Ding an sich is accessible to the subject prior to the generation of cognitive representations of the thing as an object (Solovyov 1996:77).

The subject's constructed phenomena should contain something of the unmediated data of the thing encountered in the happenstance between the thing and the subject. However, in positivist epistemology, knowledge is of representations alone. The instant that conceptualisation of the object occurs, the thinking subject is separated from the Ding an sich because being is decomposed by its abstraction 21.'[T]rue essence... is not representation...' (Solovyov 1996:75).

22.'[M] etaphysics must... transcend the world as representation' (Solovyov 1996:71). from things into objects (Solovyov 1996:94, 103). By consequence of its displacement of being, the subject emerged in Modernity as the epistemological linchpin - even to the extreme Hegelian degree as the only thing that exists beyond which no being and no understandings can be constructed (Hegel 1900:9; Solovyov 1996:118). In this period, the transcendent of the subject and the discipline that studied it - that is, metaphysics - were abandoned as meaningless (Solovyov 1996:118). Thus arose a tension in Modernity between the centrality of the thinking subject and the unaccounted for the existence of the thing (1996:121-122).

In resituating the subject, Solovyov proposes that the subject can never be placed prior to or have priority over natural processes, for the subject's own being implies both natural causality for its existence and a milieu within which its being is located (1996:121). Being, hence, should be understood as preeminent to the possibility of knowing, though it can only be known in empirical terms; without empirical experience, there is nothing to speculate about (1996:125, 134). Therefore, neither the reductively, absolute theses of analytic a priori knowledge (founded without empirical support) nor the 'pure', non-theory laden empiricism - that both underlie positivism - abide (Huemer 2002:127; Solovyov 1996:125).

Further, in the necessary acknowledgement of metaphysical dimensions of the real, it is a noteworthy point that at the very least, rationalism must assert the existence of a thinker, and empiricism that there is something that it is possible to experience through sensory observation (Solovyov 1996:136). Conversely, in the case of absolute rationalism, because '... being [is conceived as] only in our knowledge of [being] ...', the object of metaphysics, the Ding an sich, is obliterated from consideration (1996:135). Likewise, in radical empiricism, the possibility of knowledge of anything in-and-of-itself, is eradicated, as the empirically knowable must reference the experience of the thinking subject (1996:35). Solovyov, rather, proposes that the rational and the empirical aspects of epistemic theories form an undivided unity before the intervention of the thinking subject (1996:138). This, he opines, is because the reasonable and the empirical exist together in the same being by virtue of the fact that things exist and can be experienced (1996:138). Knowledge has both metaphysical and empirical components, locating its own existence simultaneously beyond and within the subject $(1996: 10,138)$.

Being in the Solovyovyian ontological-epistemology cannot be limited to the ruminations or experiences of any particular thinking subject. In its multidimensional, non-reductive complexity, being opens itself for account to the unified broadness of empirical science, philosophy and theology (1996:138, 149).

\section{Saint Thomas Aquinas' ontological- epistemology}

Within Thomism, a similar construal to Solovyov's ontologically grounded epistemology is apprehendable. 
Aquinas, of course, predates Modernity, however, his 20thcentury interlocutor, the French Thomist Jacques Maritain induces the insufficiency of Modernity's aggrandisement of the object ([1959] 1995:99). The modern object is criticised as a subjective, epistemic construal about the thing, but is not the thing: knowledge is separate from being ([1959] 1995:99). Maritain's postulate hearkens back to Saint Thomas Aquinas, for whom knowledge was construed as a coalesced reciprocity between the extant entity and the thought-about-the-thing, that is, between material thing and formal object (Summa Theologica, I, q. 1, a. 2). If truth is the encounter of being and human intellect - were a statement concerning anything existent to be true - then that statement must reflect the thing about which it refers (Maritain [1959] 1995:99). Here lies the conjunction between Solovyov and Aquinas. Indeed, contrary to Modernity's separation of being and knowing - from the realist paradigms of Aquinas and Solovyov - true knowledge cannot just be the product of the musings of a subject wherein knowledge is a self-referential hermeneutical circle that does not reach beyond its bounds of constructed meaning to the thing ([1959] 1995:105).

Unlike more contemporary epistemic realisms - determining the manner in which the subject gains access to the object Thomist realism is redirected to the ontological (Gilson 2011:18). As in the case of Solovyov, Thomism's searching out for what lies behind the subject's construction of an object - but which comes to be known through the subject's meeting with the thing - is prioritised. At the core is the postulation that being is knowable because it has simultaneous ontological and epistemological natures (Aquinas 1963:91-92). ${ }^{23}$

Aquinas' realism considers true knowledge to be more than subjective as it is determined by the being of the thing objectified by the intellect (Milbank \& Pickstock 2001:xiii, 5). In this model, cognitive processes - via observation, perception, etc. - are engaged in the path to true understanding, for the thinking subject and the extant thing are constructed as in an encounter of the subject and the universals of being (Scott 2012:388).

[T]ruth is defined by the conformity of intellect and thing... hence to know this conformity is to know truth... [T]he intellect can know its own conformity with the intellegible thing; yet it does not apprehend it by knowing of a thing 'what a thing is.' When, however, it judges that a thing corresponds to the form which it apprehends about that thing, then first it knows and expresses truth (Aquinas, Summa Theologica, I, q. 1, a. 2).

A thing, however, is not knowable by the subject in a complete way, because the intellect's knowledge of a thing - that is, 'the intelligible thing' - is not the thing itself but the knower's construction about the thing (I, q. 1, a. 2). Herein, Aquinas can be interpreted as having foreseen the Kantian critique of unconditioned knowledge of the Ding an sich (Kant [1787] 2010:15). Nevertheless, in what would be a juxtaposition to Kant, Aquinas posits - in realist fashion - that unconditioned 23.'[B]eing... is in things and in the intellect' (Aquinas, Summa Theologica, I, q. 16, a. 2-3) knowledge is accessible because the truth is not dependent on the conjecture of the thinking subject, but upon being itself (Summa Theologica, I, q. 16, a. 4).

While the modern critique of knowledge centred epistemology upon the subject, Aquinas posits that it is not solely the thinking subject's potential for knowledge that makes knowledge possible. More precisely, knowledge's actuality is a consequence of the subject's potentiality for knowledge acquisition by its engagement with being, because being possesses a manner of knowable existence (Aquinas 1993:30; Gilson 2011:19). In all certainty, were there nothing to know, there could be no true knowledge of anything; all that could hypothetically be is the indeterminate representation of an object constructed by a subject (Gilson 2011:53). Such a construction of the subject is an insufficient foundation for true knowledge, which must be reflective of being, by Aquinas' definition of 'truth' (Summa Theologica, I, q. 16, a. 3). Overwhelmingly evident in Aquinas' typology of being and knowing, is their combination in 'truth', formulated as inseparable entities (Aquinas, 2012, Summa Theologica, I, q. 16, a. 3; Gilson 2011:25).

If the thinking subject can have knowledge of being, it follows that when interpretation of such knowledge occurs, it is no longer 'of being' but is 'about being'. Consequently, cognitive representations replace the unmediated sensory experience given by the thing when thinking about an apprehended thing happens (Gilson 2011:56-57; Maritain [1959] 1995:89). Thus, being and knowing stand at a disjuncture, such that there is an epistemic caveat to truth evident in human thought (Aquinas, 2012, Summa Theologica, I, q. 1, a. 2). However, true knowledge does not refer to the subject's thoughts about being, but is clarified as knowledge of being itself (Gilson 2011:89). In this Thomist account, knowledge-of-being is interpreted as having primacy over knowledge-about-being as held by the intellect, which always mediates such knowledge.

This correspondence theory of truth - as was the case in both Aristotle and Augustine - can be accused of naiveté. But Aquinas' postulation of the nature of truth is nuanced, because he did not contend that truth is totally conformable with being, because of the fundamental role he ascribes to the subject in the process of understanding (Aquinas 2008, Truth, I, q. 1, a. 1; Aristotle [c. 350 BCE] 1984:22; Augustine 2009, Soliloquies, II, 8). For Aquinas, the truth of a statement is determined by a conformity - an 'adequation' - between the intellect of the thinking subject and the being of the thing (Truth, q. 1, a. 1). In this sense, truth is determined by being, because the being of a thing opens the thinking subject to the possibility of knowing the thing but truth is not contained within being (Truth, q. 1, a. 1). Being binds what can be known as true to that which is, but the actual 'locale' of the emergence of truth is to be found in the engagement of the thinking subject with being (Truth, q. 1, a. 1). Truth is thus not a product of being, but rather of the intellect: To what is, a statement of truth is irrelevant for the being of a thing because the true 
statement in no way impacts upon it. ${ }^{24}$ In the adequation of thinking subject to extant object, therefore, truth arises as both subjective (about the thing) and objective (of the thing).

From the Aristotelian delineation of 'science' as knowledge of the extant causes of any particular being, the principle arises that like any other set of statements purporting to be true, scientific theories should submit themselves to adequation to being (Aristotle n.d.; Aquinas n.d.). Aristotelian scientific knowledge is indisputable and perfect, because it is an adequation by the thinking subject to being which is given by nature to that subject (Aquinas n.d.; Aristotle n.d.; Aydede 1998:15; Jenkins 1997:15). In order for this to be, however, the thinking subject must assume that a particular thing to be known has existence (Jenkins 1997:18-19). More than that, the proviso is stipulated that perfect knowledge of this sort is limited to necessary truths and may not always be knowable (Aquinas n.d.; Aquinas 2012, Summa Theologica, I, q. 1, a. 5; q. 75, a. 5; q. 85, a. 3; Jenkins 1997:20-21).

Whether scientific knowledge is perfect or partial, though, the principle of knowledge remains within Thomist epistemology: held by the intellect, knowledge concerns and is informed by being itself, if it is true (Jenkins 1997:37, 49). Such knowing of being is intimate as signified by the Latin term 'intelligere' which describes the action, 'to understand', with its semantic roots in the phrase 'intus legere' (to 'read inside') (Aquinas 2012, Summa Theologica, II-II, q. 8, a. 1). In this terminology, an implicit distinction is drawn between knowledge that concerns the accidental qualities of appearance - as experienced by the senses - and the deeper knowledge that penetrates into the essence of the being of a particular thing concerning causality (II-II, q. 8, a. 1). Aquinas posited, however, that human knowledge begins with the aforementioned supposition of the existence of being and then proceeds to the sensory experience of accidental qualities which are the apparent particularities of things (Aquinas 2012, Summa Theologica, II-II, q. 8, a. 1; Floyd 2006:1; Williams 2004:506). ${ }^{25}$ Such sensory-based knowledge forms a part of a systematic effort to grasp being, even if only the immediately evident aspects thereof (Aquinas 2012, Summa Theologica, II-II, q. 8, a. 1). However, there is more to know than sensory data, for:

[T]here are many kinds of things that are hidden within, to find which human knowledge has to penetrate within... Thus, under the accidents lies hidden [for example] the nature of the substantial reality... (II-II, q. 8, a. 1).

Aquinas suggests that although having its origins within the sensorily perceivable, the supreme component of knowledge of being - that is, metaphysical knowledge - forms a part of a continuum of knowing which can reach even to the nature of being.

24.A thing is not called true... unless it conforms to an intellect... But if... [the] intellect did not exist and things did not continue to exist, then the essential of truth would in no way remain' (Aquinas, Truth, q. 1, a. 1).

25.'[H]uman knowledge begins with the outside of things... [and this] act of reasoning proceeds from something previously understood' (Aquinas, Summa Theologica, II-II, q. 8, a. 1)

\section{The congruity of eastern and western united Christian critique of epistemic reductivism}

Independently both Aquinas and Solovyov express criticism of reductivist epistemology in favour of an epistemology established in and leading to metaphysics. In the case of the latter, this critique was particularly directed toward positivism, a school of thought which had defended empiricism and rationalism as the only means to knowledge, while disregarding the seeking of causes (Comte [1864] 1896b:302-303; Carnap 1961:254). For our purposes, it is valuable to reiterate the stances of Aquinas and Solovyov. In Aquinas' assessment, true knowledge of being - from the perspective of multiple levels and through numerous approaches - is accessed by the intellect, arriving at an adequation to both what a thing is and a determination of its causality (Aquinas 2012, Summa Theologica, I, q. 1, a. 1; I-II, q. 57, a. 2; Aquinas n.d., Expositio libri Posteriorum Analyticorum, Lectio 4, Caput 2). Specifically appraising the positivist rejection of causality for the sake of empiricism and rationalism, Solovyov contended that this logic was flawed, thus he re-placed metaphysics at the heart of epistemological activity (Comte [1864] 1896a:302-303; Solovyov 1996:23, 32, 165, 168).

Broadly, in both Aquinas and Solovyov's ontologically established, realist epistemologies, a serious attempt is made to access being, acknowledgeing the role of, but unfettered by, the interpretative action of the thinking subject and her intellect. More particularly, the textual analysis undertaken identifies six themes of congruence between these philosophers.

\section{Ontology precedes epistemology}

In a time when metaphysics was flouted because of the primacy of empirical science, Solovyov resituated metaphysicsincluding ontology, one of its sub-fields - into a position of primacy over epistemology (1996:71-72). Similarly, Aquinas argued that being - the particular subject of ontological inquiry - is the source of true knowledge (Summa Theologica, I, q. 16, a. 1). Solovyov substantiated this position by postulating that if knowledge is to be knowledge of the being of a thing rather than of the constructed and interpreted knowledge of the being of a thing - metaphysics must not be concerned with epistemology, but with actual things (1996:71-72).

\section{Realism broadly embraced}

If knowing presupposes being, a realism transpires in both Aquinas and Solovyov, manifest in their mutual subscription to a correspondence theory of truth. Within Thomist ontological-epistemology, for example, true knowledge adequates to the thing about which that particular statement refers (Aquinas, Truth, q. 1, a. 2). Directing to the nature of that which corresponds - namely a cognitive representation of a thing (the 'object') - Solovyov submits that any representation implies, by its existence, the being of both the representer and the represented (1996:64). 


\section{Advocates for clarified realism}

However, in the epistemologies of Aquinas and Solovyov, a nuanced realism is apparent, involving the activity of the thinking subject in the processes of understanding's production - is apparent. Both philosopher-theologians conciliate the roles of extant being and the thinking subject in the generation of true knowledge, adequated to being (Aquinas 2012, Summa Theologica, I, q. 1, a. 2; Solovyov 1996:60).

\section{Knowledge as a continuum of understanding}

True knowledge, as determined by Aquinas and Solovyov, is not restricted to a singular mode, but is extended into multiple methodologies across the manifold layers of the existence of any particular entity. In complement, these methods lead to a continuum of knowledge about the thing apprehended from its distinct appearance beheld by the senses, to its universal share in being. Unpretentiously, Aquinas expressed this hypothesis in his affirmation that there are 'various means through which knowledge is obtained...', resulting in the thinking subject having access to 'scientific' knowledge, that is, both of the cause of the thing under scrutiny and of the effect of the cause (Summa Theologica, I, q. 1, a. 1; Expositio libri Posteriorum Analyticorum, Lectio 4, Caput 2). Knowledge of a thing, constructed in this serial manner, exhibits the oneness of epistemological systems (Solovyov 1996:149).

\section{Accessing being}

Although the thinking subject must construct its knowledge content through engagement with being, Solovyov seeks to transcend representative knowledge, which in the positivist paradigm is all that extant entities are limited to be (1996:32, 72). Indeed, apprehending the accidental qualities of a thing is the proper task of the senses coupled with the human intellect which forms representations thereof, however, Aquinas speculates, the second work of the intellect is the actual accessing of the being behind the representation (Aquinas 1999, Exposition of the 'De Trinitate' of Boethius, q. 5, a. 3).

\section{Disjuncture between a thing and thinker}

Solovyov contended that it is imperative that being is beheld as it is - being-qua-being - because knowledge constructed by the thinking subject is limited by the subject in accordance with its abilities, prior knowledge and categories of understanding of that particular subject (1996:94, 103). Therefore, as Aquinas posits, knowledge that represents a thing is not the thing it represents, but is construed as a representation of that thing (Summa Theologica, I, q. 75, a. 5). A disjunction exists, consequently, between the thing and the subject in the thought of Aquinas and Solovyov.

From these articulated points, congruence can be identified between Aquinas and Solovyov. By virtue of Aquinas' absence from Solovyov's work, it is fair to speculate that Aquinas did not influence Solovyov in a significant manner.
Still, clear correspondences are evident between these philosophical representatives of the Western and Eastern Christian traditions, most especially in their unified appeal contrary to reductivist epistemology.

\section{Conclusion}

Present espousers of positivism continue to commit the epistemic fallacy whereby being is denigrated to the empirically verifiable alone (Bhaskar [1978] 2008:16, 1998:27-28). The chemist Peter Atkins, as an illustration thereof, delineates this position (Atkins 1995):

[It is a] defensible proposition that no philosopher has helped to elucidate nature... [whereas empirical science] is on the track of ultimate truth (p. 100).

In the rejection of metaphysics, inquiry into causality is placed aside from the pursuit of human knowledge, for it is a non-empirical study. Concomitantly, the most universally apparent in all sciences - being - is evacuated. From the perspective of ontologically founded epistemology, the diminution of the primacy of being and the cessation of researching causes for the indulgence of empiricism, is suggestive of a 'science' that is devoid of depth. Veritably, the single-minded, over-simplification of being-qua-being to the constructs of the human mind and its epistemic limits as reflected in contemporary reductivist epistemologies, bear witness to this postulation.

To whatever extent empiricism is valuable, truth is manifold in its levels of being and its apprehension. Within this research, an earnest effort has been undertaken to demonstrate the importance of metaphysics to science in the exegesis of the ontological epistemologies of Saint Thomas Aquinas and Vladimir Solovyov. Herein, it is discernible that being is, in fact, of primary significance to knowledge constructed in relation with being, if indeed that knowledge purports to be true. Because of things existing, I have argued, their existence demands and deserves an account. That the thinking subject creates cognitive objects in its attempt at understanding is not sufficient, however. The congruous Christian philosophical challenge offered by Aquinas and Solovyov - in their ontological epistemologies - is for the being of things to be made plain, a task of metaphysical proportions which requires the overcoming of cognitively construed objects that limit being to the fabricated.

This duty is profoundly philosophical, and thus, I conjecture, epistemic reductivists hold to an indefensible proposition in the claim that philosophical discourse adds nought to the explanation of nature. Without causal account - no different in remaining silent about being -nature remains reduced to human perception, deprived of acknowledgement of the content of being-qua-being.

\section{Acknowledgements}

The author wishes to acknowledge the insightful commentary of this article's anonymous peer reviewers, as well as the 
comments and observations of Dr Yolandi M. Coetser, Discipline of Philosophy, Department of Philosophy, Practical and Systematic Theology, University of South Africa and the initial inspiration for this research from Fr. Richard J. Reese, Diocese of Aberdeen, Scotland.

\section{Competing interests}

The author declares that he has no financial or personal relationships that may have inappropriately influenced him in writing this article.

\section{Funding information}

Because of the funding of the National Research Foundation, this essay was first presented at the second Symposium Thomisticum, 22-24 June 2017, held in Porto, Portugal.

\section{References}

Anselm of Canterbury, Saint, 2000, 'Proslogion', in J. Hopkins (ed.), Complete philosophical and theological treatises of Anselm of Canterbury, pp. 88-112, Banning Press, Minneapolis, MN

Aquinas, Saint Thomas, 1963, Commentary on Aristotle's physics. Books I-II, transl. R.J. Blackwell, R.J. Spath \& W.E. Thirlkel, viewed 25 February 2013, from http:// dhspriory.org/thomas/Physics2.htm

Aquinas, Saint Thomas, 1993, Aquinas: Selected philosophical writings. Selected and translated with an introduction and notes by T. McDermott, Oxford University Press, Oxford.

Aquinas, Saint Thomas, [c. 1261] 1999, 'Exposition of the "De Trinitate" of Boethius', in S.F. Brown (ed.), Aquinas: On faith and reason, pp. 25-42, Hackett Publishing Company, Indianapolis, IN.

Aquinas, Saint Thomas, [c. 1252-1256] 2013, Concerning being and essence, Kindle edn., Aquinas Press, Marysville, WA

Aquinas, Saint Thomas, 2008. Truth: Volume I: Questions I-IX, transI. R.W. Mulligan, Wipf \& Stock, Eugene, OR.

Aquinas, Saint Thomas, 2012, Summa theologica. Complete American edition, Kindle Edition version, s.l.

Aquinas, Saint Thomas, n.d., Expositio libri posteriorum analyticorum: Commentary on the posterior analytics of Aristotle, in F. Larcher \& J. Kenny (eds.), viewed 02 December 2016, from http://dhspriory.org/thomas/PostAnalytica.htm

Aristotle, [c. 350 BCE] 1984, 'Categories', in J. Barnes (ed.), The complete works of Aristotle: The revised Oxford Translation, vol. 1, pp. 3-24, Princeton University Press, Princeton, NJ.

Aristotle, [c. 350 BCE] n.d., Posterior analytics, Book I, in G.R.G. Moore (ed.), viewed 02 December 2016, from http://classics.mit.edu/Aristotle/posterior.1.i.html

Atkins, P., 1995, 'Science as truth', History of the Human Sciences 8(20), 97-102. https://doi.org/10.1177/095269519500800206

Augustine, Saint, 1887, On the predestination of the saints (book I), transl. P. Holmes \& R.E. Wallis, viewed 06 December 2016, from: http://www.newadvent.org/ fathers/15121.htm

Augustine, Saint, 2009, Soliloquies, book II, viewed 06 February 017, from http:// www.newadvent.org/fathers/170302.htm

Aydede, M., 1998, 'Aristotle on episteme and nous: The posterior analytics', The Southern Journal of Philosophy XXXVI, 15-46.

Ayer, A.J., [1936] 1990, Language, truth and logic, Penguin Books, London.

Bacon, F., 1854, 'Novum organum 1620', in B. Montague (ed.), The works, pp. 343371, Parry \& MacMillan, Philadelphia, PA.

Bartholomew I., Ecumenical Patriarch, 2011, Speaking the truth in love: Theological and spiritual exhortations of ecumenical patriarch bartholomew, in J. Chryssavgis (ed.). Fordham University Press, New York.

Bhaskar, R., [1978] 2008, A realist theory of science, 2nd edn., Verso, London.

Bhaskar, R., 1998, 'Philosophy and scientific realism', in M. Scotford Archer, R. Bhaskar, A. Collier, T. Lawson \& A. Norrie (eds.), Critical realism: Essential readings, pp. 16-47, Routledge, London.

Bindley, T.H. (ed.), [1899] 1906, The oecumenical documents of the faith: The creed, three epistles of cyril, the Tome of Leo, the Chalcedon definition, 2nd edn., Methuen \& Co, London.

Boas, M., 1962, The scientific renaissance: 1450-1630, Harper Brothers, New York.

Carnap, R., 1961, Der logische Aufbau der Welt, Felix Meiner Verlag, Hamburg.

Comte, A., [1864] 1896a, The positive philosophy of Auguste Comte, in H. Martineau (ed.), vol. 1, George Bell \& Sons, London.
Comte, A., [1864] 1896b, The positive philosophy of Auguste Comte, in H. Martineau (ed.), vol. 3, George Bell \& Sons, London.

Crotty, M., 1998, The foundations of social research: Meaning and perspective in the research process, Sage, London.

Davies, M.L., 2016, 'The enlightenment: Something to think about', in M.L. Davies (ed.), Thinking about the enlightenment: Modernity and its ramifications, Electronic book, Routledge, Oxon, pp. 1-28.

Dawkins, R., 2003. A Devil's Chaplain: Selected essays by Richard Dawkins, Weidenfeld and Nicolson, London.

Dawkins, R., [2006] 2009, The God delusion, Transworld Publishers, London.

De Courten, M., 2004, History, sophia and the Russian nation: A reassessment of Vladimir Solov'êv's views on history and his social commitment, Peter Lang, Bern.

Delanty, G., 2013, Formations of European modernity: A historical and political sociology of Europe, Electronic book, Palgrave MacMillan, Houndmills.

Descartes, R., [1637] 2007, Discourse on the method of rightly conducting one's reason and seeking truth in the sciences, in J. Bennett (ed.), viewed 14 Novembe 2016, from http://www.earlymoderntexts.com/assets/pdfs/descartes1637.pdf

Desmond, W., 2005, 'Is there metaphysics after critique?', International Philosophical Quarterly 45(2), 221-241. https://doi.org/10.5840/ipq20054524

Dupré, J., 1988, 'Materialism, physicalism and scientism', Philosophical Topics 16(1), 31-56. https://doi.org/10.5840/philtopics19881612

Dushin, O.E., 2005, 'Modeli sovesti: Foma Akvinskii i Vladimir Soloviev [Models of Conscience: Thomas Aquinas and Vladimir Soloviev]', Voprosy Filosofii 3 , 149-159.

Floyd, S., 2006, 'Achieving a science of sacred doctrine', The Heythrop Journal I(47), 1-15. https://doi.org/10.1111/j.1468-2265.2006.00275.x

Frank, S. (ed.), [1950] 2001, A Solovyov anthology, transl. N. Duddington, The Saint Austin Press, London.

Gerrard, T., 1918, 'Vladimir Soloviev: The Russian Newman: Introduction', in M. D’Herbigny (ed.), Vladimir Soloviev: A Russian Newman (1853-1900), pp. 1-27, R. \& T. Washbourne, Ltd., London.

Gilson, É., 2011, Methodical realism: A handbook for beginning realists, Ignatius Press, San Francisco, CA.

Glazov, G.Y., 2016, 'Solovyov and the origins of this work', in V. Solovyov \& G.Y. Glazov (eds.), The burning bush: Writings on Jews and Judaism, pp. 3-11 University of Notre Dame Press, Notre Dame.

Gleiser, M., 2014, The Island of knowledge: The limits of science and the search for meaning, Basic Books, New York.

Gracia, J.J.E., 1992, Philosophy and its history: Issues in philosophical historiography, State University of New York Press, Albany, NY.

Haack, S., 2007, Defending science within reason: Between scientism and cynicism, Prometheus Books, Amherst, MA.

Harris, S., 2006, Science must destroy religion, viewed 10 November 2016, from http://www.huffingtonpost.com/sam-harris/science-must-destroy-reli_b_13153. html

Hawking, S.W., 2001, The universe in a Nutshell, Bantam Books, New York.

Hawking, S.W. \& Mlodinow, L., 2010, The grand design: New answers to the ultimate questions of life, Bantam Press, London.

Hegel, G.W.F., 1900, The philosophy of history, in J. Sibree (ed.), rev. edn., The CoOperative Publication Society, New York.

Heidegger, M., 1978, Gesamtausgabe 15: Seminare, Vittorio Klostermann, Frankfurt.

Heidegger, M., 2000, Introduction to metaphysics, transl. G. Fried \& R. Polt, Yale University Press, New Haven.

Heidegger, M., 2005, 'On the essence of truth and "the origin of the work of art"', in t. Medina \& D. Woods (eds.), Truth: Engagements across philosophical traditions, pp. 243-260, Blackwell Publishing. Oxford.

Hobbes, T., [1656] 1981, Computatio sive logica: Logic de corpore, Part I, in I.P.C. Hungerland, G.R. Vick \& A.P. Martinich (eds.), Abaris Books Ltd., New York.

Huemer, H. (ed.), 2002, Epistemology: Contemporary readings, Routledge, London.

Hume, D., [1748] 2008, An enquiry concerning human understanding, in J. Bennett (ed.), viewed 10 November 2016, from http://www.earlymoderntexts.com/ assets/pdfs/hume1748.pdf

Jenkins, J.I., 1997, Knowledge and faith in Thomas Aquinas, Cambridge University Press, Cambridge.

John T.S., [1976] 2011, Periphyseon: On the division of nature, Wipf and Stock Publishers, Eugene, OR.

Kanne, M., 1979, 'Saint Thomas Aquinas' division of the sciences', Transactions of the Nebraska Academy of Sciences and Affiliated Societies VII, 145-148.

Kant, I., [1784] 1996, 'An answer to the question: What is enlightenment?', in M.J. Gregor (ed.), Practical Philosophy: The Cambridge edition of the works of Immanuel Kant, Cambridge University Press, Cambridge.

Kant, I., [1783] 2007, Prolegomena [= preliminaries] to any future metaphysics that can present itself as a science, in J. Bennett (ed.), viewed 09 October 2013, from http://www.earlymoderntexts.com/pdf/kantprol.pdf

Kant, I., [1787] 2010, The critique of pure reason, The Pennsylvania State University, University Park, PA.

Ladyman, J., Ross, D., Spurrett, D. \& Collier, J., 2007, Every thing must go: Metaphysics naturalized, Oxford University Press, Oxford. 
Liat, J.K.S., 1951, 'Methods of comparative philosophy', Philosophy East and West 1(1), 10-15. https://doi.org/10.2307/1396932

Leibniz, G.W.F., [1716] 2006, Principles of nature and grace based on reason, in J. Bennett (ed.), viewed 03 May 2018, from http://www.earlymoderntexts.com/ assets/pdfs/leibniz1714a

Locke, J., [1689] 2004, in J. Bennett (ed.), An essay concerning human understanding Book II: Ideas, viewed 15 November 2016, from http://www.earlymoderntexts. com/assets/pdfs/locke1690book2.pdf

Lonergan, B.J.F., [1957] 1970, Insight: A study of human understanding, 3rd edn. Philosophical Library, New York.

Macdonald, P.A., 2009, Knowledge and the transcendent: An inquiry into the mind's relationship to god, The Catholic University of America, Washington, DC.

Maffie, J., 1975, 'Naturalism, scientism and the independence of epistemology', Erkenntnis 45(1), 1-27. https://doi.org/10.1007/BF01131838

Marion, J.-L., 1991, God without being, transl. T.A. Carlson, The University of Chicago Press, Chicago.

Maritain, J., [1959] 1995, Distinguish to unite or the degrees of knowledge, transl. G.B. Phelan, University of Notre Dame Press, Notre Dame.

Mi, C. \& Chen, R. (eds.), 2007, Naturalized epistemology and philosophy of science, Editions Rodopi, Amsterdam.

Milbank, J. \& Pickstock, C., 2001, Truth in Aquinas, Routledge, London.

Newell, W., 2009. 'Complexity and Interdisciplinarity', in L. Kiel (ed.), Knowledge management, organizational intelligence and learning, and complexity, pp. 178-193, EOLSS Publishers, Oxford.

Newton, I., 1729, The mathematical principles of natural philosophy, transl. A. Motte, Benjamin Motte, London.

Nollan, V.F., 2008, 'Translator's introduction', in V. Solovyov (ed.), The philosophical principles of integral knowledge, transl. V.F. Nollan, pp. 1-18, William B. Eerdman Publishing Company, Grand Rapids, MI.

Numbers, R.L., [1992] 2006, The creationists: From scientific creationism to intelligent design, expanded edn., University of California Press, Berkeley, CA.

Olafson, F., 2001, Naturalism and the human condition: Against scientism, Routledge, London.

Paul VI, Pope, 1964, Decree on ecumenism - Unitatis Redintegratio, viewed 08 November 2016, from http://www.vatican.va/archive/hist_councils/ii_vatican council/documents/vat-ii_decree_19641121_unitatis-redintegratio_en.h̄tml

Parker, C.H., 2007, 'Individual and community in the early modern period', in C.H. Parker \& J.H. Bentlet (eds.), Between the middle ages and modernity: Individual and community in the early modern world, pp. 1-9, Rowman \& Littlefield Publishers, Lanham.

Peacocke, A., 2001, Paths from science towards God, Oneworld Publications, London.

Pieper, J., 2006, For the love of wisdom: Essays on the nature of philosophy, Ignatius Press, San Francisco, CA.

Pickering, M., 2006, Auguste Comte: Volume 1: An intellectual biography, Cambridge University Press, Cambridge.

Pigliucci, M., 2015, 'Scientism and psuedoscience: A philosophical commentary', Bioethical Enquiry 12, 569-575. https://doi.org/10.1007/s11673-015-9665-1

Plested, M., 2012, Orthodox readings of Aquinas, Oxford University Press, Oxford.

Polkinghorne, J., 2000, Faith, science \& understanding, SPCK Publishing, London.
Poole, R., 2003, 'William James in the Moscow psychological society: Pragmatism, pluralism, personalism', in J. Delaney Grossman \& R. Rischen (eds.), William James in Russian culture, pp. 131-158, Lexington Books, Lanham.

Poole, R. 2010. 'Vladimir Solov'ëv's philosophical anthropology: Autonomy, dignity, perfectibility', in G. Hamburg \& R. Poole (eds.), A history of Russian philosophy 1830-1930: Faith, reason and the defense of human dignity, pp. 131-149, Cambridge University Press, Cambridge.

Raju, P.T., [1962] 1992, Introduction to comparative philosophy, Motilal Banarsidas Publishers, Delhi.

Rouse, J., 2002, How scientific practices matter: Reclaiming philosophical naturalism, The University of Chicago Press, Chicago, IL.

Scott, C.D., 2012, 'The death of philosophy: A response to Stephen Hawking', South African Journal of Philosophy 31(2), 384-404. https://doi.org/10.1080/02580136. 2012.10751783

Scott, C.D., 2014, A Thomistic exploration of the unity of truth in the science and religion dialogue: Seeking oneness of the human experience, Doctoral thesis, University of Pretoria, Pretoria.

Scott, C.D., 2016, 'The frontiers of empirical science: A Thomist-inspired critique of scientism', HTS Teologiese Studies/Theological Studies 72(3), 3180. https://doi. org/10.4102/hts.v72i3.3180

Solovyev, V., 1948, Russia and the universal church, The Centenary Press, London.

Solovyov, V., 1996, The crisis of Western philosophy [Against the positivists], in B. Jakim (ed.), Lindisfarne Press, Hudson, NY.

Sorrell, T., 1991, Scientism: Philosophy and the infatuation with science, Routledge, London.

Spinoza, B., [1677] 2001, Ethics: Part I. Concerning god, viewed 15 November 2016 from http://www.gutenberg.org/files/3800/3800-h/3800-h.htm

Stenmark, M., 2001, Scientism: Science, ethics and religion, Ashgate, Aldershot.

Stone, A., 2006, 'Heidegger and Carnap on the overcoming of metaphysics', in S. Mulhall (ed.), Martin Heidegger, pp. 217-244, Ashgate Publishing Limited, Aldershot.

Voegelin, E., 1948, 'The origins of scientism', Social Research 15(4), 462-494.

Von Balthasar, H., 1986, The glory of the lord: A theological aesthetics. Vol. 3: Studies in theological styles: Lay styles, T. \& T. Clark Limited, San Francisco, CA.

Walicki, A., 1979, A history of Russian thought: From the enlightenment to Marxism, transl. H. Andrews-Rusiecka, Stanford University Press, Stanford, CA.

White, T.J., 2009, Wisdom in the face of modernity: A study in Thomistic natura theology, Sapienta Press, Ave Maria, FL.

Williams, A., 2004, 'Argument to bliss: The epistemology of the Summa Theologiae, Modern Theology 20(4), 505-526. https://doi.org/10.1111/j.1468-0025.2004 .00265.x

Williams, R. \& Robinson, D., 2015, Scientism: The new orthodoxy, Bloomsbury Academic, London.

Wozniak, V., 2013, 'Vladimir S. Soloviev: Moral philosopher of unity', Journal of Markets \& Morality 16(1), 323-329.

Yannaras, C., 2006, Orthodoxy and the West: Hellenic self-identity in the modern age, Holy Cross Orthodox Press, Brookline, MA

Zenkovsky, V., 1953, A history of Russian philosophy, transl. G.K. Kline, Routledge \& Kegan Paul, Ltd., London. 